JURNAL RISET PENDIDIKAN MATEMATIKA

Volume 3 - Number 2, November 2016, (234 - 244)

Available online at http://journal.uny.ac.id/index.php/jrpm

\title{
KEEFEKTIFAN PENDEKATAN PROBLEM POSING DAN PROBLEM SOLVING DALAM PEMBELAJARAN KALKULUS II
}

\author{
Markus Palobo \\ Pendidikan Matematika, Universitas Musamus Merauke. Jalan Kamizaun Mopah Lama, Kecamatan \\ Merauke, Kabupaten Merauke, Papua 99611, Indonesia \\ Korespondensi Penulis. Email: markunmusmath@gmail.com \\ Received: $18^{\text {th }}$ May 2016; Revised:20 $0^{\text {th }}$ September 2016; Accepted: $6^{\text {th }}$ October 2016
}

\begin{abstract}
Abstrak
Penelitian ini bertujuan untuk mendeskripsikan keefektifan pendekatan problem posing dan problem solving serta membandingkan keefektifan pendekatan problem posing dengan problem solving ditinjau dari sikap mahasiswa terhadap Kalkulus dan prestasi belajar. Penelitian ini merupakan penelitian eksperimen semu dengan desain pretest-posttest non equivalent comparison group design. Populasi pada penelitian ini adalah mahasiswa Universitas Musamus Merauke. Sampel penelitian adalah mahasiswa Jurusan Pendidikan Matematika semester II yang dibagi dalam dua kelompok. Pengujian keefektifan pendekatan problem posing dan problem solving menggunakan uji one sample t-test dan untuk mengetahui pendekatan mana yang lebih efektif menggunakan uji independent sample t-test. Hasil penelitian menunjukkan bahwa (1) pendekatan problem posing efektif ditinjau dari sikap terhadap Kalkulus dan prestasi belajar; (2) pendekatan problem solving efektif ditinjau dari prestasi belajar; dan (3) pendekatan problem posing lebih efektif dari pada pendekatan problem solving ditinjau dari sikap mahasiswa terhadap Kalkulus.
\end{abstract}

Kata Kunci: pendekatan problem posing, pendekatan problem solving, sikap terhadap kalkulus, prestasi belajar

\section{THE EFFECTIVENESS OF PROBLEM POSING AND PROBLEM SOLVING APPROACH IN CALCULUS II LEARNING}

\begin{abstract}
This study aimed to describe the effectiveness of problem posing and problem solving approach, and to compare the effectiveness between problem posing and problem solving approach in terms of attitude toward Calculus and learning achievement. This study was a quasi-experimental study using the pretest-posttest non-equivalent comparison group design. The population of this study were student of Musamus University. The sample in this study were 2nd semester students of mathematics educations departement who were divided into two groups. To assess the effectiveness of the problem posing and problem solving approach, the one sample t-test was carried out and to determine the more effective approach, independent sample t-test was used. The results of this study show that (1) the problem posing approach was effective in terms of attitude towards Calculus and learning achievement; (2) problem solving approach was effective in terms of learning achievement; and (3) problem posing approach was more effective than problem solving approach in terms of students attitude toward calculus.
\end{abstract}

Keywords: problem posing approach, problem solving approach, attitude toward Calculus, learning achievement

How to Cite: Palobo, M. (2016). Keefektifan pendekatan problem posing dan problem solving dalam pembelajaran kalkulus II. Jurnal Riset Pendidikan Matematika, 3(2), 234-244. doi:http://dx.doi.org/10.21831/jrpm.v3i2.9369

Permalink/DOI: http://dx.doi.org/10.21831/jrpm.v3i2.9369 


\section{Jurnal Riset Pendidikan Matematika, 3 (2), November 2016 - 235}

Markus Palobo

\section{PENDAHULUAN}

Peraturan Menteri Pendidikan dan Kebudayaan Nomor 49 Tahun 2014 tentang Standar Nasional Pendidikan Tinggi, menuntut Program Studi untuk menghasilkan lulusan yang sesuai dengan kualifikasi KKNI (Kerangka Kualifikasi Nasional Indonesia). Sistem pembelajaran merupakan bagian penting untuk mampu menghasilkan lulusan yang berdaya saing tinggi. Sistem pembelajaran yang baik mampu memberikan pengalaman belajar kepada mahasiswa untuk membuka potensi dirinya dalam menginternalisasikan knowledge, skills dan attitudes serta pengalaman belajar sebelumnya. Kondisi pembelajaran perguruan tinggi saat ini masih cukup beragam.

Perguruan tinggi yang telah menjalankan sistem penjaminan mutu dengan baik dari level institusi sampai program studi umumnya telah melaksanakan pembelajaran yang berbasiskan capaian pembelajaran, meskipun demikian masih terdapat kendala pelaksaanaan dilapangan. Misalkan, masih terjadi ketidakjelasan apakah pilihan strategi dan metode pembelajaran merupakan pilihan yang tepat untuk memunculkan capaian pembelajaran yang telah ditetapkan.

Proses pembelajaran yang banyak dipraktekkan sekarang ini sebagian besar berbentuk penyampaian secara tatap muka (lecturing), atau penyampaian secara searah (dari dosen kepada mahasiswa). Pada saat mengikuti kuliah atau mendengarkan ceramah, mahasiswa akan kesulitan untuk mengikuti atau menangkap esensi materi pembelajaran, sehingga kegiatannya sebatas membuat catatan yang kebenarannya diragukan. Disamping itu ada kecenderungan lain yaitu mahasiswa saat ini kurang mampu menyimak. Mahasiswa kurang terbiasa dengan mencatat dengan menggunakan model "mind mapping" atau model "taking notes" lainnya. Mahasiswa merasa tentram karena bahan tayang dalam bentuk power point dapat diperoleh dari dosennya. Kebiasaan semacam ini perlu diubah, karena mahasiswa menjadi pasif. Pola proses pembelajaran dosen aktif dengan mahasiswa pasif ini efektifitasnya rendah, dan tidak dapat menumbuhkembangkan proses partisipasi aktif dalam pembelajaran. (Kementrian Pendidikan dan Kebudayaan, 2014, pp.50-53).

Menurut Undang-Undang Republik Indonesia Nomor 12 Tahun 2012 tentang Pendidikan Tinggi, dinyatakan bahwa "pembelajaran adalah interaksi antara pendidik, peserta didik, dan sumber belajar, di dalam lingkungan belajar tertentu." Berdasarkan pada pernyataan tersebut maka dalam mendeskripsikan setiap unsur yang terlibat dalam pembelajaran tersebut dapat ditengarai ciri pembelajaran yang berpusat pada mahasiswa (student centered learning). Berpusat pada mahasiswa menyatakan bahwa capaian pembelajaran lulusan diraih melalui proses pembelajaran yang mengutamakan pengembangan kreativitas, kapasitas, kepribadian, dan kebutuhan mahasiswa, serta mengembangkan kemandirian dalam mencari dan menemukan pengetahuan. Mahasiswa harus didorong untuk memiliki motivasi dalam diri mereka sendiri, kemudian berupaya keras mencapai hasil pembelajaran yang diinginkan.

Perubahan pendekatan dalam pembelajaran dari teacher centered learning menjadi student centered learning adalah perubahan paradigma, yaitu perubahan dalam cara memandang beberapa hal dalam pembelajaran yakni pengetahuan, belajar dan pembelajaran. Proses pembelajaran harus dilakukan secara sistematis dan terstruktur melalui berbagai mata kuliah dengan beban belajar yang terukur dan menggunakan metode pembelajaran yang efektif sesuai dengan karakteristik mata kuliah. Metode pembelajaran yang dapat dipilih untuk pelaksanaan pembelajaran khususnya mata kuliah yang berhubungan dengan matematika antara lain problem posing dan problem solving.

Pendekatan pembelajaran problem posing dan problem solving adalah dua di antara banyak pendekatan pembelajaran yang melibatkan aktivitas peserta didik dan juga kreativitas mereka dalam proses pembelajarannya. Siswono (2008, p.62) menyatakan problem posing merupakan tugas yang meminta siswa untuk mengajukan atau membuat soal atau masalah berdasar informasi yang diberikan, sekaligus menyelesaikan soal atau masalah yang dibuat tersebut. Pendekatan pembelajaran problem solving mempunyai pengertian sebagai proses pembelajaran yang menuntut peserta didik untuk menyelesaikan masalah, yang dapat dibuat sendiri oleh pendidik ataupun fakta nyata yang ada di lingkungan kemudian diselesaikan dalam pembelajaran di kelas, dengan berbagai cara dan teknik.

Definisi tentang pendekatan problem posing diungkapkan beberapa ahli misalnya Silver (Akay \& Boz, 2010, p.60) menyatakan "problem posing is defined as occurring when students are engaged in reformulating given problems and also when producing new problems or questions." Selanjutnya Stoyanova \& Ellerton 


\section{Jurnal Riset Pendidikan Matematika, 3 (2), November 2016 - 236}

Markus Palobo

(Bonotto \& Dal santo, 2015, p.107) menyatakan tentang problem posing yakni proses dimana, atas dasar pengalaman matematika, siswa membangun tafsiran sendiri atas situasi nyata dan merumuskannya sebagai masalah matematika yang bermakna. Selain itu tujuan pendekatan problem posing menurut English yaitu "problem posing activity makes a sensation; enables autonomous learning; diverse and flexible thinking; prevents misunderstanding and preconceptions; helps to deplete anxiety about mathematics learning by means of interactive learning environment" (Arikan \& Unal, 2015, p. 23).

Pendekatan problem solving menurut Bell (1978, p.310) yakni "general problem solving should be defined as the resolution of a situation which is regarded as a problem by the person who resolves it." Sedangkan Haylock \& Thangata (2007, pp.145-146) menyatakan bahwa problem solving adalah situasi dimana siswa menggunakan pengetahuan dan penalaran matematikanya untuk menyelesaikan kesenjangan antara yang diketahui dan tujuan yang ingin dicapai. Selanjutnya manfaat problem solving sebagai berikut "mathematical problem solving is a complex cognitive activity involving a number of processes and strategies. Problem solving has two stages: problem representation and problem execution. Successful problem solving is not possible without first representing the problem. Appropriate problem representation indicates the problem solver has understood the problem, and it guides the student toward the solution plan. Students who have difficulty representing math problems will have difficulty solving them" (Montague, 2005, p.2)

Hasil penelitian di berbagai negara, menunjukkan bahwa prestasi belajar atau hasil belajar dipengaruhi oleh berbagai hal, antara lain jenis kelamin, tingkat pendidikan orang tua, sikap terhadap matematika, dan jumlah peserta didik dalam kelas (Douglas, 1992, p.691). Hal ini mengisyaratkan bahwa perlu metode dan strategi dalam menyampaikan materi matematika, yang tidak hanya memperhatikan karakter peserta didik itu sendiri, juga memperhatikan faktor-faktor dari luar peserta didik sehingga kompetensi yang diinginkan tercapai dan hasil belajar pun meningkat. Dipertegas oleh Lianghuo, Seng, Yan, Mei, Pereira-Mendosa, \& Yee $(2005$, p.1) bahwa sikap terhadap terhadap matematika memiliki hubungan dengan prestasi belajar matematika. Pembelajaran perlu mendapat perhatian khusus terutama oleh pendidik atau guru yang tentunya untuk menumbuhkan sikap positif sehingga dapat meningkatkan hasil belajar peserta didik. Tanpa sikap yang baik dalam diri peserta didik maka akan sulit tercapai suasana belajar seperti yang diharapkan.

Popham (1995, p.179) menyatakan ranah afektif menentukan keberhasilan belajar peserta didik. Keberhasilan pembelajaran pada ranah kognitif dan psikomotor dipengaruhi oleh kondisi afektif peserta didik. Salah satu aspek afektif tersebut adalah sikap mahasiswa. Hal tersebut menunjukkan bahwa peserta didik semestinya mendapatkan kesempatan yang cukup untuk mengembangkan kemampuan kognitif, afektif dan psikomotor, namun terkadang karena keterbatasan waktu maka hanya ditekankan pada aspek kognitif saja.

Clark \& Miler (Clements \& Jones, 2008, p.70) mendefinisikan sikap sebagai "a disposition, acquired through previous experience, to react to certain things, people or events in positive ways. Attitudes represent a tendency to approach or avoid that which maintains or threatens the things one values. Like the values from which they are often derived, attitudes have an effect upon and are consistently related to beliefs and behaviour." Selanjutnya Sikap terhadap matematika menurut Zan \& Martino (Akinsola \& Olowojaiye, 2008, p.62) adalah perasaan emosional positif atau negatif terhadap matematika. Kemudian menurut Hart (Akinsola \& Olowojaiye, 2008, p.62) sikap individu terhadap matematika merupakan cara yang kompleks tentang emosi yang berhubungan dengan matematika, keyakinan matematika, meliputi sikap positif dan negatif, dan bagaimana siswa bertingkah laku terhadap matematika.

Dosen sangat berperan dalam membangun sikap positif mahasiswa terhadap mata kuliah. Penerapan pendekatan pembelajaran yang tepat dapat meningkatkan pemahaman mahasiswa tentang materi perkuliahan yang dipelajari. Hal tersebut sesuai dengan pendapat Van de walle, Karp \& Bay-Williams (2013, p.29) bahwa pemahaman berkaitan dengan sikap dan kepercayaan diri siswa. Ketika ide dipahami dengan baik maka siswa cenderung mengembangkan konsep diri yang positif dan kepercayaan atau kemampuannya untuk belajar dan memahami matematika.

Peningkatkan kemampuan pemecahan masalah dapat juga mengubah sikap peserta didik dari negatif menjadi positif. Pernyatan tersebut diungkapkan oleh Haylock \& Tangata (2007, pp.147-148) yang menyatakan bahwa hasil yang paling positif dari pengalaman sukses 
memecahkan masalah untuk murid dari segala usia adalah rasa puas yang terjadi ketika masalah tersebut akhirnya dapat diselesaikan, yang memberikan dorongan peningkatan kepercayaan diri peserta didik dan memberikan kontribusi untuk sikap positif.

Harapan utama dalam pendidikan, termasuk Pendidikan Tinggi ialah mahasiswa memperoleh prestasi belajar yang memuaskan. Lovat (2011, p.7) mengungkapkan bahwa "since the early 1990s, there has been a concentration of effort aimed at maximising student achievement in school education and rectifying the debilitating effects of failure." Hal ini juga menjadi fokus Program Studi di Universitas Musamus untuk meningkatkan prestasi belajar mahasiswa. Prestasi belajar mahasiswa untuk beberapa mata kuliah matematika misalnya Kalkulus II dari hasil pengamatan peneliti selama mengajar di beberapa Program Studi di Universitas Musamus masih belum maksimal.

Pada umumnya banyak faktor yang dapat menyebabkan prestasi belajar mahasiswa rendah. Salah satunya adalah pendekatan pembelajaran yang diterapkan dalam perkuliahan. Syah (2013, p.136) mengemukakan bahwa pendekatan belajar berpengaruh terhadap taraf keberhasilan proses belajar peserta didik. Seorang peserta didik yang terbiasa menerapkan pendekatan belajar tertentu, mungkin sekali berpeluang meraih prestasi belajar yang bermutu dibandingkan dengan peserta didik yang menggunakan pendekatan belajar lain.

Menurut Narmadha \& Chamundeswari (2013, p.115) teachers should try to make learning of Science an enjoyable experience, the one that the children will remember for a life time as Science is an on-going process and it will continue. Dari pernyatan tersebut mengandung makna bahwa dalam meningkatkan prestasi belajar mahasiswa diperlukan penerapan pendekatan pembelajaran yang dapat menumbuhkembangkan sikap positif mahasiswa terhadap pelajaran dalam hal ini matematika. Jika hal tersebut dapat dikembangkan, maka akan turut mendorong peningkatan prestasi belajar mahasiswa. Beberapa pendekatan yang dapat diterapkan diantaranya ialah pendekatan problem posing dan problem solving.

Berdasarkan uraian latar belakang tersebut diperoleh keterkaitan antara pendekatan pembelajaran dengan sikap mahasiswa terhadap pembelajaran dan prestasi belajar. Pendekatan problem posing dan problem solving memiliki karakter dan keunggulan yang dapat berpe- ngaruh positif terhadap sikap mahasiswa dan prestasi belajar. Karena itu peneliti mengambil inisiatif melakukan penelitian untuk membandingkan keefektifan pendekatan problem posing dan pendekatan problem solving ditinjau dari sikap terhadap Kalkulus dan prestasi belajar mahasiswa Universitas Musamus Merauke

Penelitian ini bertujuan untuk mendeskripsikan keefektifan pendekatan problem posing dan problem solving ditinjau dari sikap mahasiswa terhadap kalkulus dan prestasi belajar mahasiswa, serta bagaimana perbandingan antara keefektifan kedua pendekatan. Diharapkan hasil dari penelitian ini menjadi referensi bagi dosen matematika tentang pendekatan pembelajaran yang dapat diterapkan dalam perkuliahan untuk memunculkan capaian pembelajaran yang ditetapkan.

\section{METODE}

Penelitian ini merupakan penelitian eksperimen semu dengan desain pretest-posttest non equivalent comparison group design. Penelitian dilaksanakan pada bulan Januari sampai Februari 2016 di Universitas Musamus Merauke. Populasi penelitian ini adalah mahasiswa semester 2 Universitas Musamus Merauke yang berasal dari Program Studi Pendidikan Matematika, Teknik Informatika, Sistem Informatika dan Teknik Sipil. Program Studi tersebut merupakan program Studi yang menyediakan mata kuliah Kalkulus II dalam kurikulumnya pada semester kedua. Pengambilan sampel dilakukan dengan teknik sampling purposive dan terpilih mahasiswa Program Studi Pendidikan Matematika sebagai sampel penelitian. Sampel penelitian sebanyak 38 mahasiswa dikelompokkan dalam 2 kelas eksperimen dengan jumlah anggota 19 orang setiap kelas.

\section{Data, Instrumen, dan Teknik Pengumpulan Data}

Data yang diperoleh dalam penelitian ini adalah data sikap mahasiswa terhadap Kalkulus dan data prestasi belajar mahasiswa sebelum dan sesudah perlakuan. Instrumen penelitian adalah angket sikap menggunakan skala likert yang terdiri atas 30 butir pernyatan dan instrumen tes prestasi belajar berupa soal objektif yang terdiri atas 30 butir soal. Pengumpulan data dilaksanakan sebelum dan sesudah perlakuan. Sebelum perlakuan mahasiswa diberikan angket sikap dan tes prestasi belajar (pretest) untuk memperoleh data kemampuan awal mahasiswa sebelum perlakuan. Diakhir perlakuan mahasiswa kembali 


\section{Jurnal Riset Pendidikan Matematika, 3 (2), November 2016 - 238}

Markus Palobo

diberikan angket sikap dan tes prestasi belajar (posttest) untuk memperoleh data kemampuan akhir mahasiswa.

\section{Teknik Analisis Data}

Data pretest dan posttest disajikan secara deskriptif dan inferensial. Teknik analisis data dilakukan dengan cara mendeskripsikan data dan menganalisis statistik inferensial terhadap data yang diperoleh. Deskripsi data dilakukan dengan mencari rata-rata, standar deviasi, varians, skor minimal, dan skor maksimal dari data yang diperoleh, baik untuk data sebelum perlakuan, maupun untuk data setelah perlakuan. Untuk menguji apakah pendekatan problem posing dan problem solving efektif ditinjau dari sikap terhadap Kalkulus dan prestasi belajar digunakan uji one sample t-test dengan formula sebagai berikut:

$$
t=\frac{\bar{x}-\mu_{0}}{\frac{S}{\sqrt{n}}}
$$

(Tatsuoka, 1971, p. 77) dengan

$\bar{x}$ : Nilai rata-rata sampel

$\mu_{0}$ : nilai rata-rata yang ditetapkan

$\mathrm{S}$ : Standar deviasi sampel

$\mathrm{n}$ : banyak anggota sampel

Pada aspek sikap terhadap Kalkulus, nilai $\mu_{0}$ adalah 110 sedangkan pada aspek prestasi belajar nilai $\mu_{0}$ adalah 60 . Hipotesis bahwa pendekatan pembelajaran dikatakan efektif ditinjau dari sikap terhadap Kalkulus maupun prestasi belajar apabila nilai rata-rata lebih besar dari $\mu_{0}$. Pengujian hipotesis menggunakan bantuan SPSS 21 for Windows dengan kriteria keputusan pendekatan pembelajaran dikatakan efektif apabila diperoleh nilai signifikansinya lebih besar atau sama dengan 0,05 .

Sebelum melakukan uji MANOVA, terlebih dahulu dilakukan uji asumsi terhadap data sikap terhadap Kalkulus dan prestasi belajar mahasiswa, yaitu uji normalitas multivariat dan uji homogenitas matriks varians-kovarians, baik untuk data sebelum dan setelah perlakuan. Uji normalitas multivariat dilakukan menggunakan uji jarak Mahalanobis dengan kriteria keputusan bahwa data dikatakan berdistribusi normal jika sekitar 50\% data mempunyai nilai. Uji homogenitas matriks varians-kovarians dilakukan dengan menggunakan uji Box's $M$ dengan kriteria keputusan bahwa data dikatakan homogen jika nilai signifikansi $F$ lebih besar dari 0,05 . Untuk data sebelum perlakuan dilakukan uji
MANOVA untuk melihat apakah terdapat perbedaan kemampuan awal antara dua kelas sampel ditinjau dari aspek sikap terhadap Kalkulus dan prestasi belajar mahasiswa dengan menggunakan formula sebagai berikut:

$$
T^{2}=\frac{n_{1} n_{2}}{n_{1}+n_{2}}\left(\bar{y}_{1}-\bar{y}_{2}\right)^{\prime} S^{-1}\left(\bar{y}_{1}-\bar{y}_{2}\right)
$$

(Stevens, 2009, p.148) dengan:

$T^{2}: T^{2}$ Hotelling's

$n_{1}$ : banyak subjek kelompok problem posing

$n_{2}$ :banyak subjek kelompok problem solving

$\bar{y}_{1}$ : vektor rata-rata kelompok problem posing

$\bar{y}_{2}$ : vektor rata-rata kelompok problem solving $S^{-1}$ : invers matriks kovarians.

Setelah memperoleh nilai T2 Hotteling's, selanjutnya nilai tersebut ditransformasikan untuk memperoleh nilai distribusi $F$ dengan formula sebagai berikut:

$$
F=\frac{n_{1}+n_{2}-p-1}{\left(n_{1}+n_{2}-2\right) p} T^{2}
$$

Dengan $p$ merupakan banyaknya variabel terikat. Kriteria pengujiannya yakni hipotesis terdapat perbedaan rata-rata kelompok problem posing dengan kelompok problem solving dittolak jika nilai signifikansinya lebih kecil dari 0,05 . Setelah diketahui bahwa tidak terdapat perbedaan kemampuan awal antara kedua kelas sampel, maka untuk data sikap terhadap Kalkulus dan prestasi belajar setelah perlakuan pun dilakukan uji untuk melihat apakah terdapat perbedaan.

Pengujian Keefektifan pendekatan pembelajaran problem posing dan problem solving ditinjau dari sikap terhadap Kalkulus dan prestasi belajar mahasiswa menggunakan rumus MANOVA. Setelah diketahui bahwa terdapat perbedaan keefektifan, maka terhadap data tersebut dilakukan uji independent t-test untuk melihat perbandingan pendekatan problem posing dengan pendekatan problem solving ditinjau dari sikap terhadap kalkulus dan prestasi belajar mahasiswa. dengan menggunakan formula sebagai berikut:

$$
\begin{aligned}
t= & \frac{\bar{y}_{1}-\bar{y}_{2}}{\sqrt{S^{2}\left(\frac{1}{n_{1}}+\frac{1}{n_{2}}\right)}} \\
& \text { Dengan } S^{2}=\frac{\left(n_{1}-1\right) s_{1}{ }^{2}+\left(n_{2}-1\right) s_{2}{ }^{2}}{n_{1}+n_{2}-2}
\end{aligned}
$$

(Stevens, 2009, p. 147) dengan:

$\bar{y}_{1}$ : nilai rata-rata sampel dengan pendekatan problem posing 
$\bar{y}_{2}$ : nilai rata-rata sampel dengan pendekatan problem solving

$s_{1}^{2}$ : varians sampel dengan pendekatan problem posing

$s_{2}{ }^{2}$ : varians sampel dengan pendekatan problem solving

$n_{1}$ : jumlah subjek kelompok problem posing

$n_{2}$ : jumlah subjek kelompok problem solving

Pengujian hipotesis perbandingan dalam penelitian ini menggunakan bantuan SPSS 20 for Windows dengan kriteria keputusan pendekatan problem posing lebih efektif dibandingkan dengan pendekatan problem solving diterima jika nilai signifikansinya lebih kecil dari 0,025 .

\section{HASIL DAN PEMBAHASAN}

Pelaksanaan pendekatan pembelajaran problem posing dan problem solving dilaksanakan sebanyak delapan pertemuan untuk masingmasing pendekatan pada kelas yang berbeda. Data hasil penelitian disajikan secara deskriptif dan inferensial. Deskripsi data sikap mahasiswa terhadap Kalkulus untuk kelas problem posing dan kelas problem solving menyajikan nilai ratarata, standar deviasi, skor minimal, skor maksimal dan kriteria pada data pretest dan data posttest seperti pada Tabel 1 .

Tabel 1. Deskripsi Data Sikap Mahasiswa terhadap Kalkulus Kelas Problem Posing

\begin{tabular}{lcc}
\hline \multicolumn{1}{c}{ Deskripsi } & Pretest & Posttest \\
\hline Jumlah Responden & 18 & 18 \\
Rata-rata & 100,61 & 118,17 \\
Standar Deviasi & 8,766 & 10,147 \\
Skor Minimal Ideal & 30 & 30 \\
Skor Maksimal Ideal & 150 & 154 \\
Skor Minimal dicapai & 81 & 102 \\
Skor Maksimal dicapai & 118 & 134 \\
Kriteria & Cukup & Baik \\
\hline
\end{tabular}

Nilai rata-rata mahasiswa untuk kelas problem posing sebelum perlakuan sebesar 100,61 termasuk dalam kategori cukup baik, meningkat menjadi 118,17 setelah perlakuan yang merupakan kategori baik. Skor terendah yang diperoleh mahasiswa sebelum perlakuan sebesar 81 dan skor tertinggi sebesar 118. Setelah perlakuan skor terendah mahasiswa menjadi 102, sedangkan skor tertinggi 134. Sedangkan deskripsi untuk data sikap terhadap kalkulus pada kelas problem solving disajikan pada Tabel 2.
Tabel 2. Deskripsi Data Sikap Mahasiswa terhadap Kalkulus Kelas Problem Solving

\begin{tabular}{lcc}
\hline \multicolumn{1}{c}{ Deskripsi } & Pretest & Posttest \\
\hline Jumlah Responden & 19 & 19 \\
Rata-rata & 99,89 & 109,74 \\
Standar Deviasi & 99,89 & 109,74 \\
Skor Minimal Ideal & 30 & 30 \\
Skor Maksimal Ideal & 150 & 153 \\
Skor Minimal dicapai & 89 & 93 \\
Skor Maksimal dicapai & 114 & 124 \\
Kriteria & Cukup & Cukup \\
\hline
\end{tabular}

Nilai rata-rata mahasiswa yang belajar dengan menggunakan pendekatan problem solving sebelum perlakuan 99,89 mengalami perubahan setelah perlakuan menjadi 109,74 yang tergolong kategori cukup baik. Skor terendah mahasiswa kelas problem solving sebelum perlakuan 89 dan skor tertingginya 114. Setelah diberikan pembelajaran Kalkulus dengan pendekatan problem solving diperoleh nilai terendah mahasiswa sebesar 93 dan nilai tertinggi sebesar 124. Data prestasi belajar mahasiswa pada mata kuliah Kalkulus II pada Tabel 3 dan Tabel 4.

Tabel 3. Deskripsi Data Prestasi Belajar Mahasiswa Kelas Problem posing

\begin{tabular}{lcc}
\hline \multicolumn{1}{c}{ Deskripsi } & Pretest & Posttest \\
\hline Jumlah Responden & 18 & 18 \\
Rata-rata & 22,22 & 65,92 \\
Standar Deviasi & 6,67 & 11,74 \\
Skor Minimal Ideal & 0 & 0 \\
Skor Maksimal Ideal & 100 & 100 \\
Skor Minimal dicapai & 10 & 46,67 \\
Skor Maksimal dicapai & 33,3 & 86,67 \\
Kriteria & Tidak lulus & Sedang \\
\hline
\end{tabular}

Pada Tabel 3 diperoleh data rata-rata prestasi belajar sebelum perlakuan kelas problem posing sebesar 22,22 termasuk kategori tidak lulus, meningkat menjadi 65,92 setelah perlakuan yang temasuk kategori sedang. Skor terendah yang diperoleh mahasiswa sebelum perlakuan sebesar 10 dan skor tertinggi sebesar 33,3. Setelah perlakuan skor terendah mahasiswa menjadi 46,67 sedangkan skor tertinggi 86,67.

Tabel 4. Deskripsi Data Prestasi Belajar Mahasiswa Kelas Problem Solving

\begin{tabular}{lcc}
\hline \multicolumn{1}{c}{ Deskripsi } & Pretest & Posttest \\
\hline Jumlah Responden & 19 & 19 \\
Rata-rata & 23,5 & 68,59 \\
Standar Deviasi & 7,3 & 11,77 \\
Skor Minimal Ideal & 0 & 0 \\
Skor Maksimal Ideal & 100 & 100 \\
Skor Minimal dicapai & 10 & 46,67 \\
Skor Maksimal dicapai & 36,67 & 86,67 \\
Kriteria & Tidak lulus & Sedang \\
\hline
\end{tabular}


Pada mahasiswa yang menggunakan pendekatan problem solving nilai rata-rata prestasi belajar sebelum perlakuan 23,5 meningkat setelah perlakuan menjadi 68,59. Skor terendah mahasiswa sebelum perlakuan 10 dan skor tertingginya 36,67. Setelah diberikan pembelajaran Kalkulus dengan pendekatan problem solving diperoleh nilai terendah mahasiswa sebesar 46,67 dan nilai tertinggi sebesar 86,67. Secara terjadi peningkatan rata-rata pada kedua kelas setelah perlakuan, yang menunjukkan bahwa kedua pendekatan dapat memberikan konstribusi positif terhadap prestasi belajar mahasiswa.

Uji normalitas dan homogenitas data sikap mahasiswa terhadap Kalkulus dan prestasi belajar mahasiswa sebelum dan setelah perlakuan, baik untuk kelas problem posing, maupun untuk kelas problem solving secara berturutturut dapat dilihat pada Tabel 5 dan Tabel 6.

Tabel 5. Hasil Uji Normalitas Multivariat

\begin{tabular}{ccc}
\hline Kelas & $\begin{array}{c}\text { Sebelum } \\
\text { Perlakuan }\end{array}$ & $\begin{array}{c}\text { Setelah } \\
\text { Perlakuan }\end{array}$ \\
\hline Problem Posing & $44,46 \%$ & $44,46 \%$ \\
Problem Solving & $42,10 \%$ & $36,84 \%$ \\
\hline
\end{tabular}

Berdasarkan Tabel 5 untuk data sebelum dan setelah perlakuan, pada kelas problem posing diperoleh persentase nilai $\boldsymbol{d}_{i}{ }^{2}$ yang lebih kecil dari $\chi^{2}(\mathbf{3} ; \mathbf{0}, \mathbf{5})$ yaitu 2,365 adalah berturut-turut $44,46 \%$ dan $44,46 \%$. Hal ini mengindikasikan bahwa data sebelum dan setelah perlakuan untuk kelas problem posing memenuhi asumsi distribusi normal multivariate. Persentase data sebelum dan setelah perlakuan pada kelas problem solving diperoleh persentase nilai $\boldsymbol{d}_{i}{ }^{2}$ yang lebih kecil dari $\chi^{2}(\mathbf{3} ; \mathbf{0 , 5})$ adalah berturut-turut $42,10 \%$ dan $36,84 \%$. Hal ini mengindikasikan bahwa data sebelum dan setelah perlakuan untuk kelas problem solving tidak memenuhi asumsi distribusi normal multivariat. Meskipun demikian menurut Stevens (2009, p.221) data hasil penelitian dapat diasumsikan berdistribusi normal karena jumlah sampelnya banyak, sehingga pengujian statistik tetap menggunakan uji statistik parametik yakni uji MANOVA.

Tabel 6. Hasil Uji Homogenitas Multivariat

\begin{tabular}{ccc}
\hline & $\begin{array}{c}\text { Sebelum } \\
\text { Perlakuan }\end{array}$ & $\begin{array}{c}\text { Setelah } \\
\text { Perlakuan }\end{array}$ \\
\hline M Box's & 3,622 & 13,477 \\
$\boldsymbol{F}$ & 0,574 & 2,036 \\
Sig & 0,773 & 0,57 \\
\hline
\end{tabular}

Dari Tabel 6 diketahui bahwa data sebelum perlakuan memiliki nilai $F$-test adalah 0,547 dengan nilai signifikan Box's $M$ diperoleh 0,773 lebih besar dari 0,05. Sedangkan untuk data setelah perlakuan memiliki nilai $F$-test adalah 2,036 dengan nilai signifikan Box's $M$ diperoleh 0,57 lebih besar dari 0,05. Maka dapat disimpulkan bahwa varians kovarians populasi untuk data sebelum dan setelah perlakuan adalah sama, sehingga asumsi homogenitas varians kovarians terpenuhi.

Hasil uji mengenai keefektifan pendekatan problem posing ditinjau dari aspek sikap mahasiswa terhadap Kalkulus dan prestasi belajar mahasiswa dapat dilihat pada Tabel 7 .

Tabel 7. Hasil Uji Keefektifan Pendekatan Problem Posing

\begin{tabular}{ccc}
\hline Variabel & $\boldsymbol{t}$ & Sig. \\
\hline Sikap terhadap Kalkulus & 3,414 & 0,0015 \\
Prestasi belajar & 2,139 & 0,0235 \\
\hline
\end{tabular}

Berdasarkan hasil perhitungan untuk sikap terhadap Kalkulus diperoleh nilai signifikansi 0,0015 yang lebih kecil dari 0,05. Hal ini berarti bahwa pada taraf signifikansi $5 \%$ pendekatan problem posing efektif ditinjau dari sikap siswa terhadap Kalkulus. Keberhasilan mahasiswa dalam menyelesaikan soal-soal Kalkulus yang mereka buat sendiri menjadi salah satu faktor yang berperan meningkatkan sikap positif mahasiswa terhadap Kalkulus.hal ini sesuai dengan pendapat Haylock \& Tangata (2007, pp.147-148) yang menyatakan bahwa hasil yang paling positif dari pengalaman sukses menyelesaikan masalah untuk murid dari segala usia adalah rasa puas yang terjadi ketika masalah ini akhirnya dapat diselesaikan, yang memberikan dorongan peningkatan kepercayaan diri peserta didik dan memberikan kontribusi untuk sikap positif terhadap matematika. Dipertegas oleh pendapat Brown dan Walter (Effandi \& Norulbiah, 2011, p.688) yang menyatakan bahwa pembelajaran problem posing dapat meningkatkan sikap positif siswa dan menumbuhkan respon siswa terhadap pembelajaran matematika.

Kegiatan mengajukan soal sendiri menjadi faktor kedua menurut peneliti yang menjadi penyebab peningkatan sikap positif mahasiswa. Mahasiswa sering merasa cemas ketika diberikan soal-soal oleh dosen kerena takut tidak dapat menyelesaikan soal tersebut. Pembelajaran problem posing memungkinkan mahasiswa untuk menyusun soal sendiri sehingga dapat 
meminimalkan kecemasan mahasiswa pada ketakutan tidak mampu menyelesaikan soal tersebut. Hal inilah yang menyebabkan mahasiswa Jurusan Pendidikan Matematika Universitas Musamus khususnya semester 2 yang belajar dengan pendekatan problem posing merasakan suasana gembira dalam pembelajaran Kalkulus II. Hasil ini sesuai dengan penelitian Akay \& Boz (2010) yang menunjukkan bahwa problem posing efektif meningkatkan sikap mahasiswa calon guru matematika pada mata kuliah Analisis-II.

Dari Tabel 7 diperoleh juga bahwa untuk prestasi belajar mahasiswa nilai signifikansi 0,0235 lebih kecil dari 0,05 . Hal ini berarti bahwa pada taraf signifikansi $5 \%$ pendekatan problem posing efektif ditinjau dari prestasi belajar mahasiswa. Hasil ini sesuai dengan beberapa penelitian seperti penelitian Isnawan (2014) yang menunjukkan bahwa pendekatan problem posing efektif ditinjau dari prestasi belajar atau prestasi. Seluruh tahapan dalam pembelajaran problem posing berperan dalam meningkatkan prestasi belajar mahasiswa, meskipun waktu penelitian yang singkat namun diperoleh bahwa seluruh kegiatan dalam pendekatan berhasil meningkatkan prestasi belajar mahasiswa.

Proses pembelajaran berlangsung selama 6 kali pertemuan dengan materi terdiri atas dua kompetensi dasar. Tes prestasi belajar berbentuk soal pilihan ganda sebanyak 30 butir soal yang tergolong kategori sulit untuk mahasiswa papua sehingga rata-rata prestasi belajar mahasiswa tidak begitu tinggi meskipun demikian lebih dari $70 \%$ mahasiswa tuntas berdasarkan KKM. Selama ini mahasiswa terbiasa dengan soal essai dengan jumlah soal yang relatif sedikit, sehingga ketika diberikan soal pilihan ganda ada beberapa mahasiswa dengan kemampuan rendah cenderung tidak mengerjakan soal dengan serius sehingga masih terdapat yang tidak tuntas.

Prestasi belajar mahasiswa untuk kelas problem posing memiliki rata-rata 65,92 yang termasuk kategori sedang dan sudah memenuhi kriteria ketuntasan minimal (KKM) yang ditetapkan sebelumnya. Selain itu diperoleh bahwa sebanyak $72,22 \%$ mahasiswa telah memenuhi KKM prestasi belajar sesuai dengan yang telah memenuhi target yang direncanakan. Meskipun rata-rata dan proporsi ketuntasan yang diharapkan telah tercapai, namun hampir semuanya berada pada kategori sedang, sedangkan pada kategori tinggi hanya terdapat 3 mahasiswa. Terdapat penelitian yang mendukung hasil penelitian ini yakni penelitian Ghasempour,
Bakar, \& Jahanshahloo (2013) yang menyatakan bahwa ada berbagai keunggulan problem posing yakni dapat merangsang kemampuan berpikir tingkat tinggi sehingga dapat meningkatkan pemahaman siswa terhadap materi yang dipelajari. Selain itu, hal tersebut juga didukung oleh hasil penelitian Amiluddin \& Sugiman (2016) yang menunjukkan bahwa problem posing berpengaruh positif terhadap prestasi belajar mahasiswa.

Hasil uji mengenai keefektifan pendekatan problem solving ditinjau dari aspek sikap mahasiswa terhadap Kalkulus dan prestasi belajar mahasiswa dapat dilihat pada Tabel 8 .

Tabel 8. Hasil Uji Keefektifan Pendekatan Problem Solving

\begin{tabular}{ccc}
\hline Variabel & $\boldsymbol{t}$ & Sig. \\
\hline Sikap terhadap Kalkulus & $-0,108$ & 0,4575 \\
Prestasi belajar & 3,181 & 0,0025 \\
\hline
\end{tabular}

Berdasarkan hasil perhitungan dengan menggunakan untuk sikap terhadap Kalkulus pada kelas problem solving diperoleh nilai signifikansi 0,4575 yang lebih besar dari 0,05. Hal ini berarti bahwa pada taraf signifikansi $5 \%$ pendekatan problem solving tidak efektif ditinjau dari sikap siswa terhadap Kalkulus. Pendekatan ini yang sebelumnya diharapkan efektif seperti pada beberapa penelitian lainnya namun hasil uji hipotesis menunjukkan tidak efektifnya pendekatan ditinjau dari sikap mahasiswa.

Faktor pendekatan pembelajaran yang tergolong baru bagi mahasiswa menjadi salah satu dugaan penyebab hasil ini, selain itu padatnya kegiatan penyelesain setiap pertemuan menjadi penyebab lainnya sikap mahasiswa tidak tidak memenuhi KKM pada kelas problem solving. Penelitian yang dilaksanakan pada masa rehat mahasiswa setelah ujian akhir semester menurut penelitian menyebabkan kejenuhan bagi sebagian mahasiswa yang memiliki rencana istirahat dibandingkan harus melanjutkan kuliah.

Rata-rata sikap mahasiswa terhadap Kalkulus setelah perlakuan sebesar 109,74 yang tergolong cukup baik. Proporsi mahasiswa yang memenuhi KKM untuk sikap terhadap Kalkulus meningkat dari 10,57\% sebelum perlakuan menjadi $42,11 \%$ setelah perlakuan. Hasil ini menunjukkan bahwa sikap mahasiswa sudah lebih baik dibandingkan sebelum perlakuan. Diperoleh juga bahwa mahasiswa yang tidak tuntas semuanya berada pada ketegori cukup baik, jadi tidak ada lagi yang berada pada level kurang maupun tidak baik. Belum efektifnya pendekat- 


\section{Jurnal Riset Pendidikan Matematika, 3 (2), November 2016 - 242}

Markus Palobo

an problem posing menunjukkan perlunya perbaikan dalam penelitian selanjutnya untuk lebih memperhatikan faktor-faktor yang dapat meningkatkan sikap positif peserta didik. Hasil ini merupakan dampak salah satu kelemahan problem solving yang diungkapkan Killen (2009, pp.249-250) bahwa beberapa siswa tidak merasa senang terhadap pembelajaran problem posing terutama siswa dengan kemampuan lemah.

Dari Tabel 8 diperoleh untuk prestasi belajar mahasiswa pada kelas problem solving nilai signifikansi 0,0025 lebih kecil dari 0,05. Hal ini berarti bahwa pada taraf signifikansi $5 \%$ pendekatan problem solving efektif ditinjau dari prestasi belajar. Pendekatan problem solving dalam penelitian ini efektif ditinjau dari prestasi belajar mahasiswa pada mata kuliah Kalkulus II. Seluruh kegiatan dalam problem solving mulai dari memahami masalah, menentukan solusi, sampai diskusi hasil pengerjaan setiap kelompok menjadi pendukung meningkatnya prestasi belajar mahasiswa. Temuan ini sejalan dengan hasil penelitian Wijayanti \& Sugiman (2013), bahwa pendekatan problem solving efektif ditinjau dari prestasi belajar matematika siswa.

Semua langkah-langkah pembelajaran tersebut membantu mahasiswa meningkatkan pemahaman mereka pada materi Kalkulus II sehingga prestasi belajar mereka memenuhi KKM yang ditetapkan. Hasil ini didukung penelitian Isnawan (2014) yang memperoleh bahwa pendekatan problem solving mampu meningkatkan prestasi belajar peserta didik khususnya pada siswa kelas X SMA. Lembar kerja mahasiswa yang disusun untuk kelas problem solving setiap kegiatannya menyajikan masalahmasalah dengan berbagai langkah-langkah untuk menyelesaikannya. Setiap kegiatan mengharuskan mahasiswa untuk menyelesaikan setiap masalah dengan berbagai metode yang memungkinkan melalui kegiatan diskusi. Hal tersebut menjadi salah satu faktor yang berhasil meningkatkan pemahaman mahasiswa pada materi Kalkulus II. Seluruh langkah-langkah dalam pendekatan ini terbukti dapat meningkatkan prestasi belajar mahasiswa. Dalam penelitian Sardin (2014) juga diperoleh bahwa pendekatan problem solving efektif ditinjau dari prestasi matematika siswa SMA kelas XI.

Hasil uji mengenai apakah terdapat perbedaan kemampuan awal antara kedua kelas sampel sebelum diberikan perlakuan dan perbedaan keefektifan pendekatan problem posing dan problem solving ditinjau dari sikap terhadap
Kalkulus dan prestasi belajar mahasiswa disajikan pada Tabel 9.

Tabel 9. Hasil Uji Perbedaan Rata-rata

\begin{tabular}{lcc}
\hline \multicolumn{1}{c}{ Hotelling's Trace } & $\boldsymbol{F}$ & Sig. \\
\hline Sebelum perlakuan & 0,206 & 0,892 \\
Setelah perlakuan & 8,156 & 0,000 \\
\hline
\end{tabular}

Dari Tabel 9, diperoleh informasi bahwa nilai signifikansi $F$ lebih besar dari 0,05 untuk data sebelum perlakuan dan lebih kecil dari 0,05 untuk data setelah perlakuan. Artinya, untuk sebelum perlakuan, kedua kelas tersebut pada dasarnya memiliki kemampuan awal yang setara dan untuk setelah perlakuan, terdapat perbedaan keefektifan pendekatan pembelajaran problem posing dan problem solving ditinjau dari sikap terhadap Kalkulus dan prestasi belajar.

Setelah diketahui bahwa terdapat perbedaan keefektifan antara kedua pendekatan, maka akan dilakukan uji independent sample t-test untuk melihat bahwa pendekatan problem posing lebih efektif dibandingkan pendekatan problem solving ditinjau dari sikap terhadap Kalkulus dan prestasi belajar. Hasil uji pengujian dapat dilihat pada Tabel 10.

Tabel 10. Hasil Uji Independent sample t-test

\begin{tabular}{cccc}
\hline Variabel & $\boldsymbol{t}$ & Beda Rata-rata & Sig. \\
\hline $\begin{array}{c}\text { Sikap terhadap } \\
\text { Kalkulus }\end{array}$ & 2,471 & 8,430 & 0,0095 \\
Prestasi belajar & $-0,69$ & $-2,66$ & 0,2975 \\
\hline
\end{tabular}

Berdasarkan perhitungan diperoleh informasi bahwa $t$ hitung sebesar 2,471 dengan nilai signifikannya yakni 0,0095 lebih kecil dari 0,025 . Hal ini berarti bahwa pada taraf signifikan 5\% pendekatan problem posing lebih efektif dibandingkan dengan pendekatan problem solving ditinjau dari sikap terhadap Kalkulus. Hasil penelitian menunjukkan bahwa pendekatan problem posing lebih efektif dibandingkan pendekatan problem solving ditinjau dari sikap terhadap Kalkulus. Pendekatan problem posing yang memberikan ruang bagi mahasiswa mengajukan soal sendiri menyebabkan sikap positif mahasiswa meningkat pada kelas ini. Hasil ini sesuai dengan penelitian Isnawan (2014) yang memperoleh bahwa pendekatan problem posing lebih efektif dibandingkan pendekatan problem solving ditinjau dari sikap terhadap matematika.

Mahasiswa memiliki tingkat kecemasan yang rendah karena ketakutan pada soal yang akan sulit diselasaikan dengan mengajukan soal sendiri yang terjadi pada kelas problem posing. Hal tersebut berhasil meningkatkan sikap maha- 
siswa terhadap Kalkulus. Namun, pendekatan problem solving lebih memprioritaskan pada kegiatan menyelesaikan masalah yang sudah ada sebelumnya. Perbedaan tingkat kesulitan soal pada kedua kelas ini menjadikan kelompok problem solving lebih rendah dibandingkan kelompok problem posing ditinjau dari sikap terhadap Kalkulus. Adanya beberapa mahasiswa yang kesulitan dalam menyelesaikan masalah yang diberikan sehingga menyebabkan sikap mahasiswa terhadap Kalkulus tidak sebaik kelas problem posing.

Dari Tabel 10 diperoleh untuk prestasi belajar nilai $t$ hitung sebesar $-0,69$ dengan nilai signifikannya yaitu 0,2975 lebih besar dari 0,025 . Hal ini berarti bahwa pada taraf signifikan $5 \%$ pendekatan problem posing tidak lebih efektif dibandingkan dengan pendekatan problem solving ditinjau dari prestasi belajar. Hasil penelitian menunjukkan bahwa pendekatan problem posing tidak lebih efektif dibandingkan pendekatan problem solving ditinjau dari prestasi belajar Kalkulus II.

Kelas problem posing dan kelas problem solving memiliki rata-rata prestasi belajar yang berbeda namun tidak signifikan. Pada kelas problem solving diperoleh rata-rata sebesar 68,59 yang justru lebih tinggi dibandingkan dengan rata-rata kelas problem posing yaitu 65,92. Langkah-langkah pembelajaran pada kedua kelas terbukti berhasil meningkatkan prestasi belajar mahasiswa pada mata kuliah Kalkulus II. Hal ini dapat dilihat pada peningkatan proporsi ketuntasan mahasiswa pada prestasi belajar sesuai dengan KKM yang ditetapkan. Secara deskriptif terlihat bahwa jumlah mahasiswa yang tuntas pada pendekatan problem posing lebih banyak dibandingkan pada kelas problem solving.

\section{SIMPULAN}

Hasil penelitian menunjukkan bahwa pendekatan problem posing efektif ditinjau dari sikap terhadap Kalkulus dan prestasi belajar mahasiswa. Sedangkan untuk pendekatan problem solving efektif ditinjau dari prestasi belajar mahasiswa pada mata kuliah kalkulus II. Disimpulkan juga bahwa pendekatan problem posing lebih efektif dibandingkan dengan pendekatan problem solving ditinjau dari sikap terhadap Kalkulus.

\section{DAFTAR PUSTAKA}

Akay, H. \& Boz, N. (2010). The effect of problem posing oriented analisis-II course on attitude toward mathematics and mathematics self-efficacy of elementary prospective mathematics teacher. Australian Journal of Teacher Education, 35 (1), 60-75.

Akinsola, M. K. \& Olowojaiye, F. B., (2008). Teacher instructional methods and student attitudes towards mathematics. International Electronic Journal of Mathematics Education, 3 (1), 61-73.

Amiluddin, R., \& Sugiman, S. (2016). Pengaruh problem posing dan PBL terhadap prestasi belajar, dan motivasi belajar mahasiswa pendidikan matematika. Jurnal Riset Pendidikan Matematika, 3(1), 100-108. doi:http://dx.doi.org/10.21831/jrpm.v3i1. 7303

Arikan, E. E. \& Unal, H. (2015). An investigation of eighth grade students' problem posing skills (turkey sample). International Journal of Research in Education and Science (IJRES), 1 (1), 2330.

Bell, F. H. (1978). Teaching and learning mathemathics (in secondary school). $\left(2^{\text {nd }}\right.$ ed.). Dubuque, IO: Wn, $\mathrm{C}$ Brown Company Publisher.

Bonotto, C. \& Dal Santo, L. (2015). On the relationship between problem posing, problem solving, and creative in the primary school. Dalam Cai, J. \& Middleton, J. (Ed.). Mathematical Problem Posing from Research to Effective Practice. New York, NY: Springer.

Clements, P. \& Jones, J. (2008). The adversity trining handbook: a practical guide to understanding \& changing attitudes. London, UK: Kogan Page.

Douglas, A. G. (1992). Handbook of research on matemathics teaching learning. New York, NY: Macmillan Publishing Company.

Effandi, Z. \& Norulbiah, N. (2011). A preliminary analysis of students' problem posing ability and its relationship to attitudes towards problem solving. Research Journal of Applied Sciences, Engineering and Technology, 3 (9), 866870.

Ghasempour, Z., Bakar, N., \& Jahanshahloo, G.R. (2013). Innovation in teaching and 
learning through problem posing task and metacognitive strategies. International Journal of Pedagogical Innovations, 1 (1), 53-62.

Haylock, D. \& Thangata, F. (2007). Key concepts in teaching primary mathematics. London, UK: SAGE Publication Ltd.

Isnawan, M. G. (2014). Perbandingan keefektifan pendekatan problem solving dengan problem posing pada pembelajaran logika ditinjau dari aspek prestasi belajar matematika, kemampuan metakognitif, dan sikap siswa terhadap proses pembelajaran matematika di SMA. (studi eksperimen pada siswa kelas $\mathrm{X}$ SMA negeri 1 Lingsar). Tesis, tidak dipublikasikan. Universitas Negeri Yogyakarta.

Kementerian Pendidikan dan Kebudayaan. (2014). Buku kurikulum pendidikan tinggi. Jakarta: Kemendikbud.

Killen, R. (2009). Effective teaching strategies: lessons from research and practice $\left(5^{\text {th }}\right.$ ed.). South Melbourne: Cengange Learning.

Lianghuo, F., Seng, Q. K., Yan, Z., Mei, Y. S., Pereira-Mendoza, L., \& Yee, L. P. 2005. Assessing singapore students' attitudes toward mathematics and mathematics learning: findings from a survey of lower secondary students. Diakses 12 Agustus 2015 dari https://repository.nie.edu.Sg../CRP24_03 FLHConf05(EARCOME)

Lovat, T. (2010). The new values education: a pedagogical imperative for student wellbeing. Dalam Lovat, T., Toomey, R., \& Clement, N. (Ed.). International Research Handbook of Values Education and Student Wellbeing. New York, NY: Springer. Hal 3-18.

Montague, M. (2005). Math problem solving for primary elementary sudents with disabilities. Diakses pada tanggal 15 agustus 2015 dari http://165.139.150.129/intervention/Math $\% 20$ Problem\%20Solving\%20for\%20Prim ary\%20Elementary\%20Students\%20with \%20Disabilties.pdf Error! Hyperlink reference not valid.
Syah, M. (2013). Psikologi pendidikan: suatu pendekatan baru. Bandung: Rosdakarya.

Narmadha, U. \& Chamundeswari, S. (2013). Attitude towards learning of science and academic achievement in science among students at the secondary level. Journal of Sociological Research, 4 (2), 114-124.

Popham, R. J. (1995). Classroom assesment: what teacher need to know. Boston, MA: Allyn and Bacon.

Republik Indonesia. (2012). Undang-undang RI nomor 12, tahun 2012, tentang pendidikan tinggi.

Sardin, S. (2015). Perbandingan keefektifan pembelajaran guided inquiry dan problem solving ditinjau dari prestasi belajar peluang, kemampuan penalaran, dan sikap siswa terhadap matematika. PYTHAGORAS: Jurnal Pendidikan Matematika, 10(2), 189-200. doi:http://dx.doi.org/10.21831/pg.v10i2.9 158

Stevens, J. P (2009). Applied multivariate statistics for the social sciences $\left(4^{\text {th }}\right.$ ed.) New York, NY: Routlege Taylor \& Francis Group.

Siswono, T. Y. E. (2008). Identifikasi proses berpikir kreatif siswa dalam pengajuan masalah (problem posing) matematika berpandu dengan model wallas dan creative problem solving (CPS). Buletin Pendidikan Matematika, 6 (2), 1-16.

Tatsuoka, M. M. (1971). Multivariate analysis: techniques for educational andpsychological research. New York, NY: John Wiley \& Sons, Inc.

Van de walle, J. A., Karp, K. S., \& BayWilliams, J. M. (2013). Elementary and middle shool mathematics: teaching developmentally ( $8^{\text {th }}$ ed.). Boston, MA: Pearson Education.

Wijayanti, T., \& Sugiman, S. (2013). Keefektifan pendekatan CTL dan problem solving ditinjau dari prestasi belajar matematika dan religiusitas siswa. PYTHAGORAS: Jurnal Pendidikan Matematika, $\quad 8(2), \quad 213-223$. doi:http://dx.doi.org/10.21831/pg.v8i2.89 51. 